\title{
The Transport Revolution on Land and Sea: Farming, Fishing, and Railways in Great Britain, 1840-1914
}

\author{
Robert M. Schwartz \\ Mount Holyoke College
}

\begin{abstract}
:
The introduction and expansion of rapid rail transportation in Great Britain helped transform sea fishing and make fresh fish a new commodity of mass consumption. In agriculture the rail network greatly facilitated the shift from mixed cereal farming to dairy farming. To demonstrate the timing and extent of these changes in food production this article blends history and geography to create a spatial history of the subject. Using the computational tools of GIS and text mining, spatial history charts the expanding geography and size of the fresh fish industry and documents the growing concern among fishermen of over-fishing. In agricultural, huge flows of cheap wheat from the United states caused a crisis in British wheat farming, forcing many farmers to convert arable land to pasture for use in dairy farming. Given the growing demand for fresh milk in cities and increased availability of rapid rail transport in rural areas, dairy farming replaced wheat farming in outlying counties such as Wiltshire, the example examined here.
\end{abstract}

Keywords: historical GIS, text mining, railways, sea fishing, dairy farming

\footnotetext{
${ }^{1}$ This article is based on research supported by a Collaborative Research Grant from the National Endowment for the Humanities (RA-50577-060). The GIS data on British railways was produced from M. H. Cobb's remarkable atlas of The Railways of Great Britain, a Historical Atlas, 2 vols. (Shepperton: Ian Allan, 2005). This work was part of a European Science Foundation initiative (Eurocores) and the project within it, "Water, Road and Rail: The Development of European Waterways, Road and Rail Infrastructures: A Geographical Information System for the History of European Integration (18252005)," directed by Jordi Martí Henneberg, Inventing Europe grant FP-005.
}

HoST - Journal of History of Science and Technology 12, pp. 106-131

DOI 10.2478/host-2018-0005 


\section{Introduction}

On land and sea, the transport revolution of the nineteenth century-railways, steamships, and telegraphy_transformed agriculture and sea fishing in Great Britain. By sea, the expansion of the railway system had by the 1850 s connected major fishing ports with London and other inland cities, bringing about the rise and spread of a new commodity - fresh fish. While the quantity of fish caught, shipped, and consumed increased dramatically, the transport revolution accelerated the flow of American wheat and meat into Britain, depressing prices and aggravating an agrarian depression (18761893). Consequently, as journalist Richard Jefferies of Wiltshire put it, English farmers suffered "losses year after year." ${ }^{2}$ Amid agricultural distress, however, the extension of high-speed rail transit into the countryside beginning in the 1860 s led to a partial recovery through the rise of the fresh milk trade. In both cases high speed rail transport had multiple and shifting effects.

Pursuing these histories yields a better understanding of the relationship of rail transportation with changes in land use, in agrarian practice, in sea fishing, and in food production generally. In so doing, this article presents a mixed methods investigation, blending historical GIS, computer-assisted qualitative data analysis (CAQDA), and narrative to create a spatial history of change over time and geographic space. The common concern of this approach is the identification, description, and explanation of patterns contained in geo-referenced data and in textual documents. The identification of shifting geographic patterns, such as the evolution of the railway network from the 1830 to the eve of World War I in this research, shows the growth, extent, and intensity of interconnections in multiple dimensions, as suggested in the following list:

- the links between London, major industrial centers in the northwest, Atlantic commerce flowing through Liverpool, mining regions in the northeast and southern Wales,

${ }^{2}$ Richard Jefferies, "Steam on Country Roads," in Field and Hedgerow, being the last essays of Richard Jefferies, ed. J. Baden Jefferies, 230-240 (London: Longmans, Green, and Co., 1889), 238.

HoST - Journal of History of Science and Technology 12, pp. 106-131

DOI 10.2478/host-2018-0005 
- communications via commerce, newspapers, and mail by rail, first among urban areas and provincial towns, and then including rural districts as the network expanded into heretofore remote areas,

- the circulation of food stuffs from producing to consuming areas.

Studying the varied growth in extent and intensity of these interconnections, and the speed of geographic movement, permits us to gauge the degree of market integration, the shifting prosperity of different regions, and the cultural integration of a developing nation.

Changing geographic patterns, however, often cannot be explained and interpreted though maps and visualizations alone. How the coming of rail transport to fishing ports and their distant markets affected fishermen and fish merchants requires typical historical detective work, searching for evidence in textual sources such as newspapers, meetings of fishing industry members, and testimony presented to government officials. For farmers and fishermen, the cost of rail transport was, of course, a critical issue. The cost of rail conveyance, however, was not a simple function of the distance between a sending and receiving station. Shipping policies and freight rates distorted distance and proximity because rates favored long-distance shipping and in effect penalized short hauls. Rail transport of American grain from the port of Liverpool in the northwest to London in the southeast of the country was cheaper than sending it though the adjoining county (Cheshire) to the nearby city of Chester. This one example illustrates why evidence from textual sources is an essential component in the practice of spatial history. Furthermore, collections of textual documents (corpora) are typically bulky, consisting of hundreds or thousands of pages. CAQDA greatly facilitates the systematic analysis of large corpora such as the British Parliamentary Papers. The result yields insights into attitudes and experiences of fishermen within 
the cartographic framework of historical GIS. ${ }^{3}$

In spatial analysis there are differing scales of geographic resolution to consider for the activities under study. In agriculture, for example, the production of wheat can be investigated at local, regional, national, and international/global levels of activity-in so far as the available information permits. In the case of Great Britain from 1840 to 1914 , there is evidence on the production of wheat and milk at the level of the parish (local), the county (region), England and Wales (nation) and world markets (international). Within this hierarchy of scales, interconnections among them can produce effects from top-down and from bottom-up as a change in one spatial unit/ level prompts changes in others. ${ }^{4}$ In the case of wheat, the transport revolution on land and sea served to newly connect the fortunes of wheat farmers in Kansas (USA), for example, and their counterparts in Wiltshire County, England. As the growing surpluses from Kansas were shipped to Britain, wheat prices fell in Wiltshire and all other wheat producing regions of England. In addition to steamships and telegraphy, the expansion of railways in the United States and Great Britain was a driver of these inter-related changes.

\footnotetext{
3 Nigel Fielding and César A. Cisneros-Puebla, "CAQDAS-GIS Convergence. Toward a New Integrated Mixed Method Research Practice?,” Journal of Mixed Methods Research 3 (2009): 349-370. For comprehensive manual see H.R. Bernard, A. Wutich, and G.W. Ryan, Analyzing Qualitative Data: Systematic Approaches (New York: SAGE Publications, 2016). For leading examples that blend GIS and text mining, see articles by Ian Gregory and his associates: David Cooper and Ian N. Gregory, "Mapping the English Lake District: A Literary GIS," Transactions of the Institute of British Geographers 36, no. 1 (2010): 89-108; Ian N. Gregory and Andrew Hardie, "Visual Gisting: Bringing Together Corpus Linguistics and Geographical Information Systems," Literary and Linguistic Computing 26, no. 3 (2011): 297-314; Patricia Murrieta-Flores et al., "Automatically Analyzing Large Texts in a GIS Environment: The Registrar General's Reports and Cholera in the 19th Century," Transactions in GIS 19, no. 2 (2014): 296-320. For examples from different historical periods and approaches, see the collection of articles in Gregory and Alistair Geddes, eds., Toward Spatial Humanities: Historical GIS and Spatial History (Bloomington, ID: Indiana University Press, 2014). For new work blending spatial history and spatial humanities, see Trevor M. Harris and John Corrigan, "Deep Mapping and the Spatial Humanities," International Journal of Humanities \& Arts Computing: A Journal of Digital Humanities 7, no. 1/2 (2013): 170-175; David J. Bodenhamer, John Corrigan and Trevor M. Harris, Deep Maps and Spatial Narratives, The Spatial Humanities (Bloomington, ID: Indiana University Press, 2015); Bodenhamer, Corrigan and Harris, eds., The Spatial Humanities: GIS and the Future of Humanities Scholarship, Spatial Humanities (Bloomington, ID: Indiana University Press, 2018).

${ }^{4}$ Neil Brenner, "Between Fixity and Motion: Accumulation, Territorial Organization and the Historical Geography of Spatial Scales,” Environment and Planning D: Society and Space 16 (1998): 459-81.
} 
As for the historiographical context of this article, a few remarks will suffice. Spatial history, as Richard White argues, differs from the "linguistic turn," "the cultural turn," or "the spatial turn" because it promises no dramatic transformation in the ways of doing history. ${ }^{5}$ It is collaborative by encouraging or requiring work among programmers, geographers, historians, and the like; it is also collaborative by regenerating the blending of geography and geographical thinking with history. ${ }^{6}$ As practiced in this article, it differs from versions of digital or spatial humanities concerned with discourse on "spatial ontologies" and symbolic spatial representation. This article also stands apart from the practice of defining "spaces" as sites of gendered or produced hierarchies, notions that sometime lead to reifications. ${ }^{7}$ Characteristically, spatial historians use a variety of visualizations as means of discovery and interpretation. Perhaps most importantly spatial historians use new computational methods such as GIS and graphic visualizations in an effort to ask new questions, reexamine historical problems, and discover new understandings. ${ }^{8}$

Moving forward, let us turn first to examine the evolution of the railway network. A subsequent section will describe the impact of rail transport on sea fishing and the meaning of this transformation as expressed by fishermen, representatives of the industry, and government officials. A final section describes the changing relationship between rail transport and agriculture, focusing on the development of dairy farming and the fresh milk trade.

\footnotetext{
${ }^{5}$ Richard White, "What is Spatial History," Stanford Spatial History Lab, 1 February 2010: 1-6, available on: https://web.stanford.edu/group/spatialhistory/media/images/publication/what_is_spatial_history_ pub20020110.pdf (accessed August, 15, 2018).

${ }^{6}$ A.R.H. Baker, Geography and History: Bridging the Divide (Cambridge University Press, 2003).

${ }^{7}$ Kümin Beat and Cornelie Usborne, "At Home and in the Workplace: a Historical Introduction to the 'Spatial Turn," History and Theory 52, no. 3 (2013): 305-18; Nicolas Bauch, "Digital GeoHumanities: Visuallizing Geographical Thought," International Journal of Humanities and Arts Computing 11, no. 1 (2017): 1-15. Mike Crang, "The promises and perils of a digital geohumanities." Cultural Geographies 22, no. 2 (2015): 351-360.

${ }^{8}$ Ian N. Gregory and Paul S. Ell, Geographical Information Systems: Their Application to Historical Research (Cambridge, England: Cambridge University Press, 2008). White, "What is Spatial History," 6.
} 
The timing and extent of rail expansion in England and Wales is revealing example of temporal and spatial change. In the early years of development, the construction of new lines, in the eyes of contemporaries, demonstrated "great feats" of British engineering. 9 A prominent example was the London to Birmingham rail line. Completed in 1837-38 by the engineer Robert Stephenson, it carved and terraced its way through some 100 miles of valleys and hills, pushing aside untold tons of earth here, tunneling there, and raising huge embankments there (Figure 1). All was necessary to maintain a maximum critical grade of one-foot rise over 330 feet. ${ }^{10}$

\footnotetext{
9 Samuel Smiles, The Life of George Stephenson, Railway Engineer (London: J. Murray, 1859), preface.

${ }^{10}$ Jack Simmons and Gordon Biddle. The Oxford companion to British railway history from 1603 to the 1990s (Oxford; New York: Oxford University Press, 1997), 281-289 and 426.
} 


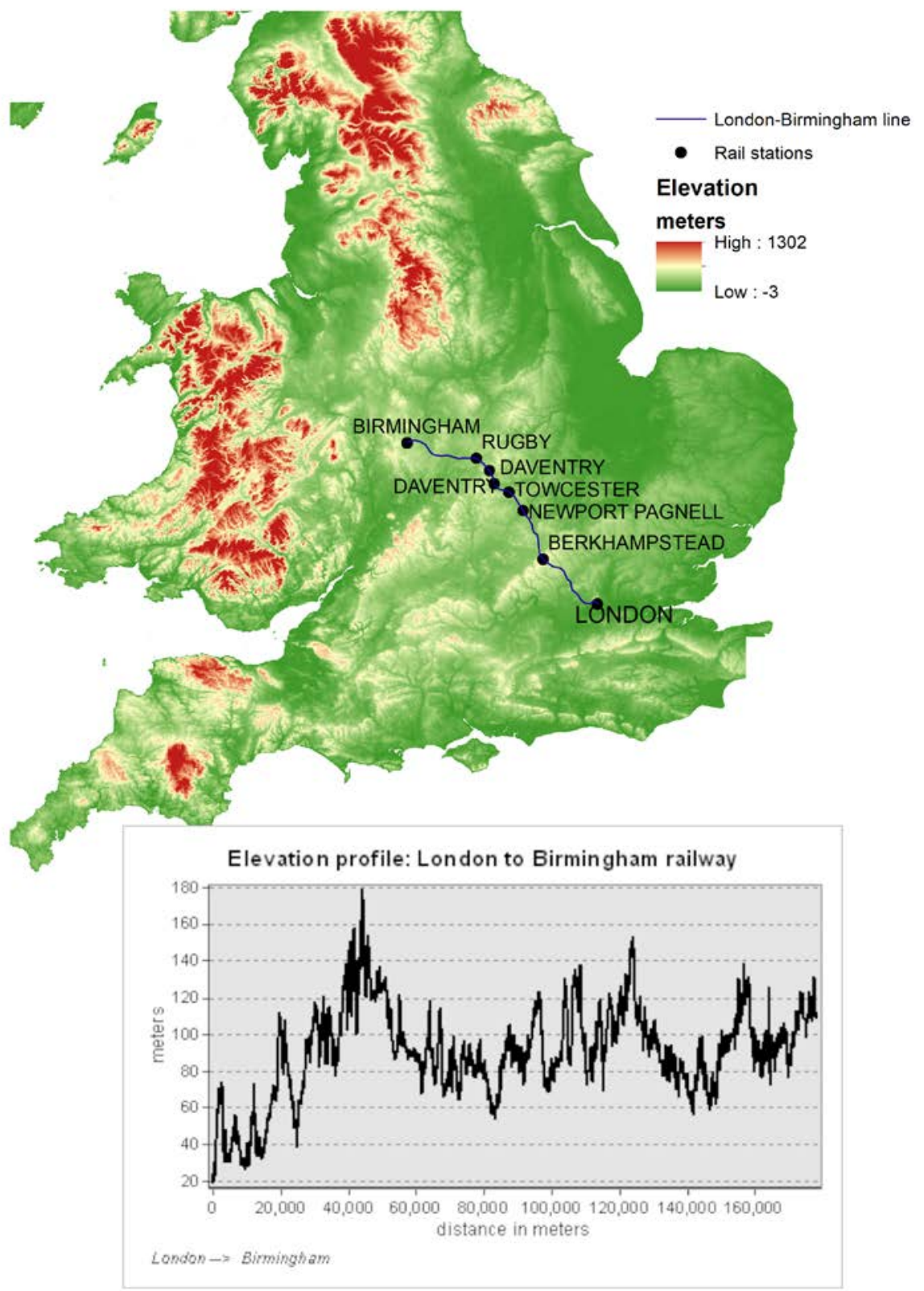

Figure 1 - The London to Birmingham Railway Line

Sources: the georeferenced data on rail lines and station is described in note 1 . The digital elevation model pictured here was constructed by the author from data from NASA's

Shuttle Radar Topography Mission (SRTM) images (2000), distributed by the United States Geological Service. The elevation profile was produced using the elevation data and the rail lines in ESRI's ArcGIS.

HoST - Journal of History of Science and Technology 12, pp. 106-131

DOI 10.2478/host-2018-0005 
In the decades that followed technological advances-more powerful locomotives, steel rails (as opposed to iron), more effective braking systems-facilitated the extension of railways into the countryside and areas of more rugged terrain such as central and northern Wales and the uplands of northern England. The increasing demand for rail services as well as competition among Britain's private rail companies for customers drove expansion farther. Figure 2 shows the extent of railway expansion at four points in time: $1850,1870,1880$, and 1920 to indicate the relatively greater expansion in the decades before the $20^{\text {th }}$ century. Indeed, as Figures 6 and 7 show, by the 1880 s the average distance to the nearest railways station in rural parishes in England and Wales was less than 5 kilometers. 


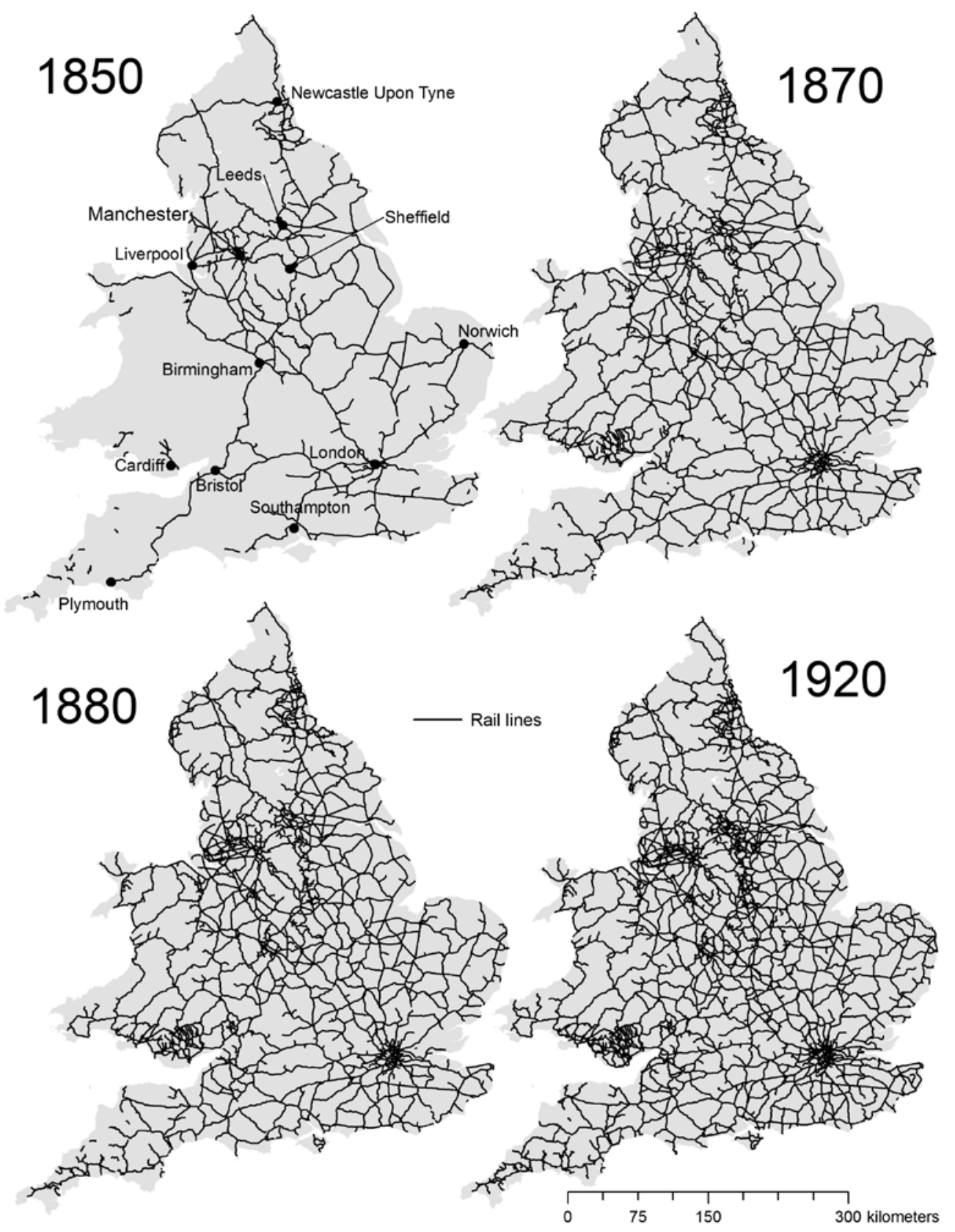

Figure 2 - Expansion of the rail network Sources: see note 1 .

HoST - Journal of History of Science and Technology 12, pp. 106-131

DOI 10.2478/host-2018-0005 


\section{Railways and Sea Fisheries}

The Government's recognition that food from the sea was vital to national well-being was repeatedly voiced through a series of Parliamentary enquiries that began in 1863 with the Royal Commission on Sea Fisheries. ${ }^{11}$ To Thomas Huxley (President) and three other commissioners, the charge was "to inquire into the Sea Fisheries of Our United Kingdom of Great Britain and Ireland, with the view of increasing the supply of a favourite and nutritious article of food for the benefit of the Public (...)" ${ }^{12}$ In taking up their responsibilities the commissioners went so far as to claim that the food "of the sea around our coasts bears a far higher proportion to that the land (...). [the] most frequented fishing grounds are much more prolific of food than the same extent of the richest land." ${ }^{13}$ The harvesting of more and more fish from the sea, thought the commissioners, was of great national importance.

Requiring two years to complete (1863-65), the commission visited 127 ports: 23 in Ireland, 21 in Scotland and 83 in England and Wales. In each port the basic question put to each witness was "Whether the supply of fish from sea fisheries is increasing, stationary, or diminishing?" ${ }^{14}$ Not surprisingly, the responses by the fishermen varied by experience and by sea port. Overall, however, reports of abundance and of decline in fish stocks were more or less equal across the map. Some fisherman reported more abundant fish in recent years; others, diminished catches.

Another question routinely asked concerned access to rail transportation. By the 1860 s, rail accessibility had expanded greatly (see Figure 2). Although some ports still lacked

${ }^{11}$ Parts of this discussion on sea fishing draw on my research for two previous articles that emphasized methods. There readers can find a specific steps of text mining with MaxQDA, computer-assisted qualitative analysis in Robert Schwartz, "Digital Partnership: Combining Text Mining and GIS in a Spatial History of Sea Fishing in the United Kingdom, 1860-1900," International Journal of Humanities and Arts Computing 9, no. 1 (2015): 36-56; and "Food, farms, and fish in Great Britain and France, 1860-1914: A mixed-methods spatial history," in The Routledge Companion to Spatial History, eds. Ian Gregory, Don DeBats, Don Lafreniere, 414-436 (New York: Routledge, 2018).

${ }_{12}$ BPP [British Parliamentary Papers], Report of the commissioners appointed to inquire into the sea fisheries of the United Kingdom, Vol. I. The report, and appendix, i.,1866.

${ }^{13}$ Ibid, xvii.

${ }^{14}$ Ibid, Vol. II. Minutes of evidence and index, testimony of 21 December 1863, Torcross, Devonshire, p. 390, questions 18.124-148, 1866. 
a rail connection, most of them were more or less well served. Indeed, as early as the 1840s, the major ports of Great Grimsby, Hull, and Yarmouth shipped a growing quantity of fresh fish both to London and to the major manufacturing cities of Leeds, Manchester, and Birmingham (see Figure 3).

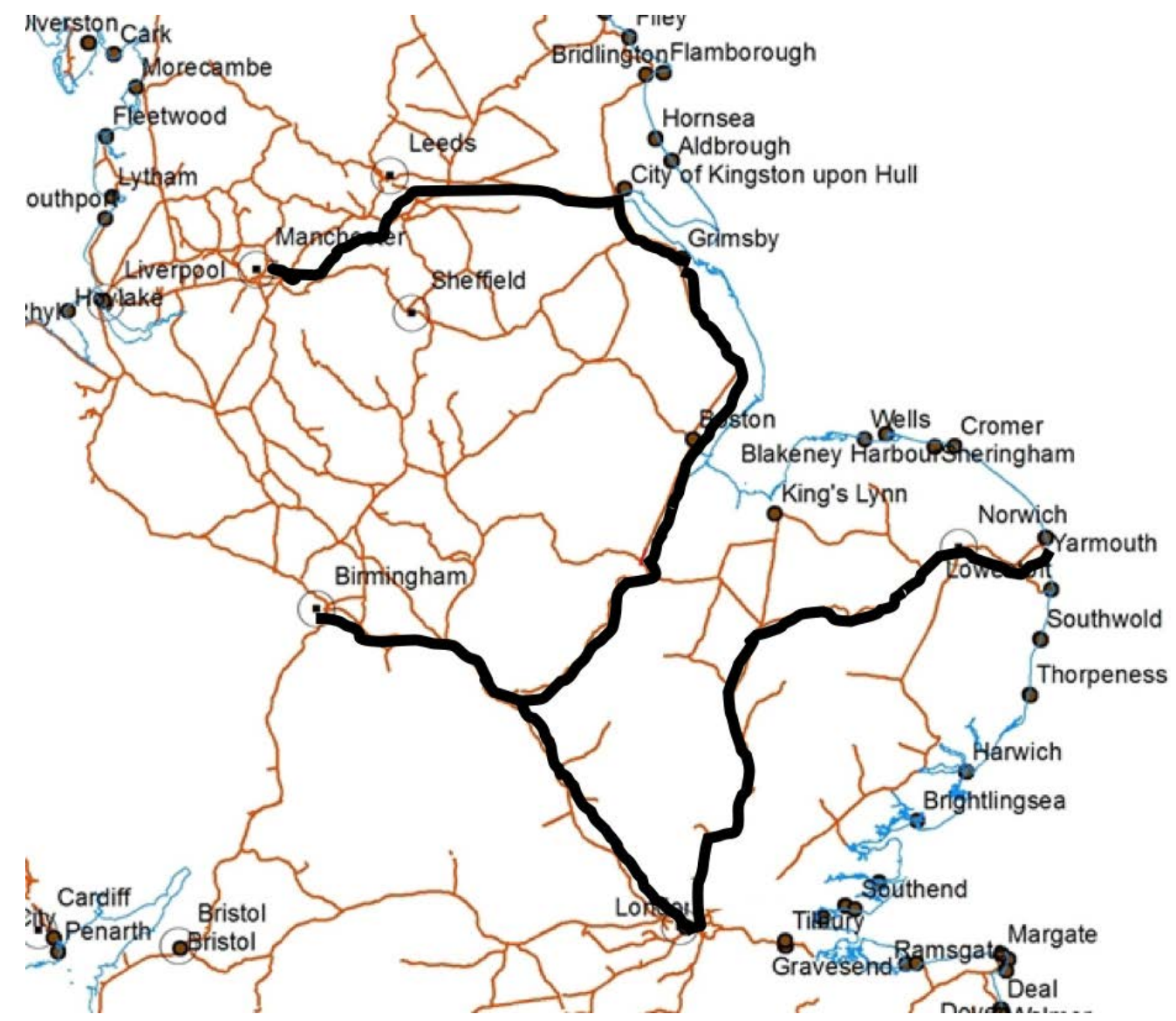

Figure 3 - Rail connections from Grimsby and Yarmouth to major cities, 1840s

Sources: rail lines, stations, and station locations are described in note 1; darkened lines added by the author.

Not surprisingly, in their testimony, fishermen often spoke of the transforming effects of rail transport. In the London port of Billingsgate, William Marchant, with 42 years' experience as a fisherman and fish salesman, noted two aspects of transformation. The increase in trawlers had tripled the size of the catch for the London market and the 
coming of the railways had greatly altered the whole trade. ${ }^{15}$

\begin{abstract}
When I was a boy there was only one steam boat in the Thames, there were no railroads, no ice houses or anything of that sort; all the fish for the London market came up the river. Now they come from a hundred various channels, from Grimsby by the Great Northern Railroad, from other places by the South-Eastern [Railway], and from Harwich, Lowestoft and Yarmouth by the Great Eastern [Railway]. There are tenfold now what they used to be when they only came by water.
\end{abstract}

London was not alone. In the southwest port of Plymouth, John Buchan spoke at length about the changes that railways brought. A decade ago, he said, all fish caught were sold in the local market, but now, he continued, the increasing number of landed fish of all types was sent to London and at higher prices. Moreover, thanks to the coming of a second, competing railway, carriage rates have declined and facilities have improved. Fifteen or twenty years ago "the price of fish in London was fabulous" because of the difficulty of getting it there; but now with 10 different railways connected to London the fish are "brought from all quarters to the capital's market. Only in the last ten days I have seen what I never saw before-that is, herrings sorted in bulk in a railway truck and sent to London (...). A few years ago [we] would never have dreamt of sending herrings to London." 16

Not all fishermen were always so enthusiastic about the railways. In Hull, William Markrow, recalled wasteful difficulties during the early years of rail service. Then, the prices for carriage to London were so high that much of the very large catch had to be thrown overboard. Fifteen years later, things had change for the better as railways reduced their rates. Indeed, "fish from Hull is selected by all the principal towns in England in preference to fish even from London and all other parts. A very large quantity (...) brought to Hull goes to Bath, Cheltenham, and even to Exeter, Glasgow, and Edinburgh, and all the midland towns." ${ }^{17}$ Likewise, in the manufacturing towns:

\footnotetext{
15 Ibid, testimony of William Marchant, pp. 271-272, question, 12.440.

${ }^{16}$ Ibid, Plymouth, Devonshire, 22 December, 1863, p. 3.

${ }^{17}$ Ibid, Hull, 3 0ctober 1863, pp. 156-57.
} 
For the last 17 years I have been travelling all over England, Scotland, and Ireland at the expense of the North-Eastern Railway Company to open markets. In many towns I went to there was not a fishmonger's shop and never had been; and it was just a chance to have a few fish brought in by a hawker travelling with a donkey. There are now four, six, or more fishmongers in such towns, all of them getting a living, and all of them taking their fish from Hull. ${ }^{18}$

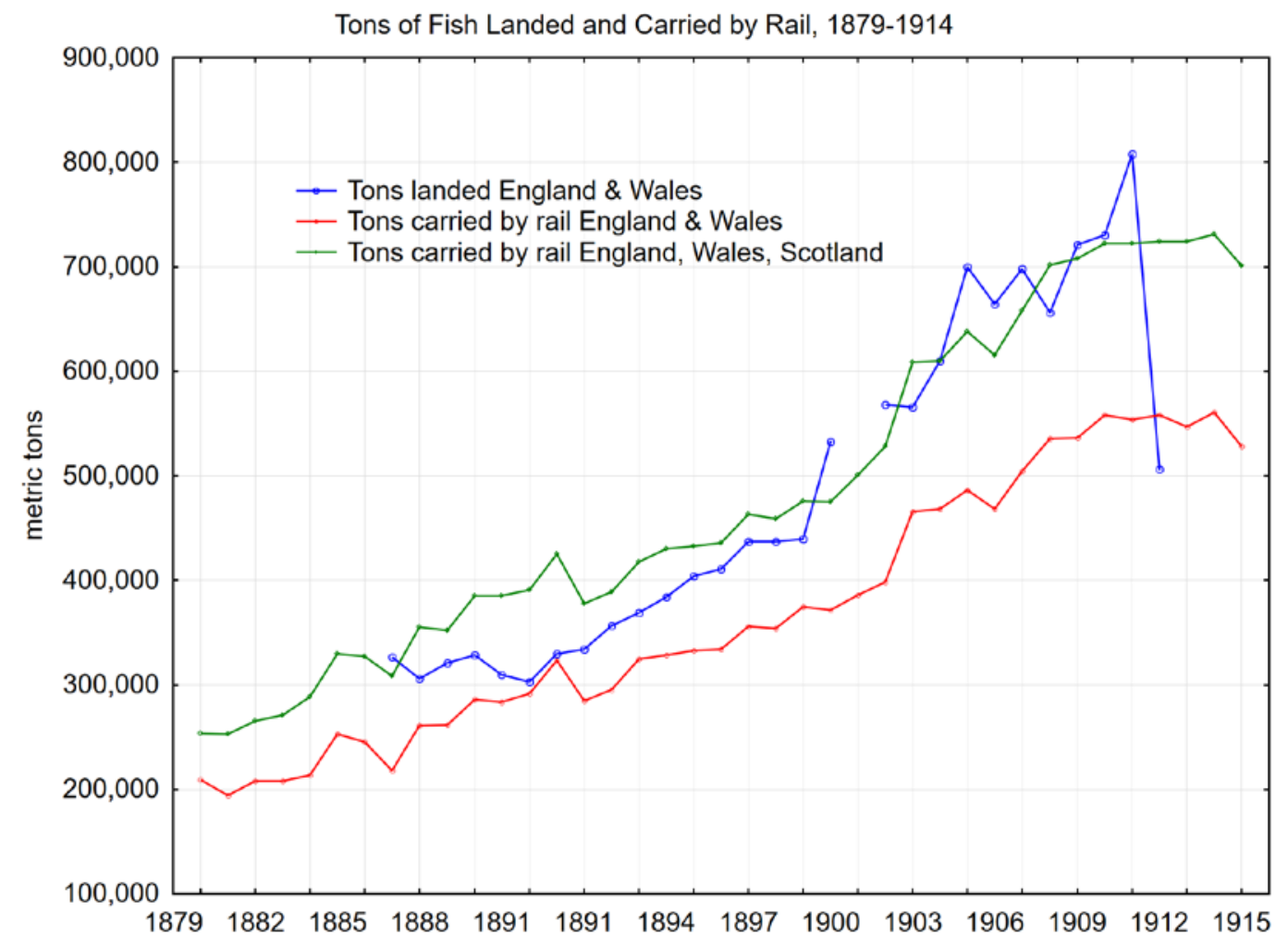

Figure 4 - Tons of fish landed and conveyed by rail, 1879-1914

Sources: Figure created by the author. British Parliamentary Papers, Return of the Quantity of Fish conveyed Inland by Railway from each of the principal Fishing Ports of England and Wales, Scotland, and Ireland in the Year 1878, 1879-1902; Board of Agriculture and Fisheries, Annual Report of Proceedings under Acts Relating to Sea Fisheries for the Year 1903; Board of Agriculture and Fisheries, Annual Report on Sea Fisheries for the Year 1914; 1887 (36) Statistical Tables and Memorandum relating to Sea Fisheries of United Kingdom, including Return of Quantity of Fish conveyed Inland by Railway from Principal Ports of England and Wales, Scotland and Ireland, 1881-86 Table V, pp. 24-36.

${ }^{18}$ Ibid, p. 161.

HoST - Journal of History of Science and Technology 12, pp. 106-131

DOI 10.2478/host-2018-0005 
The opening of new inland markets in England, Wales, and Scotland; the growing demand for fish; and the increased use of steam-powered trawlers further fortified the partnership of rail transport and sea fishing. Sea fishing had been industrialized. ${ }^{19}$ And its scale can be measured in various ways. Figure 4 displays the increase of fish landed and carried by rail. Following the curve that includes English and Welsh rail carriage to Scotland suggests that William Markrow's travels to open markets in Edinburgh and Glasgow on behalf of the North-Eastern Railway Company was but one example of an expanding practice.

The growth of the fisheries over geographic space and time also deserves attention. Figure 5 compares tons of fish landed in the fisheries of England and Wales in 1886 and 1901.

${ }^{19}$ John M. Knauss, “The Growth of British fisheries during the industrial revolution,” Ocean Development \& International Law 36 (2005): 1-11. 


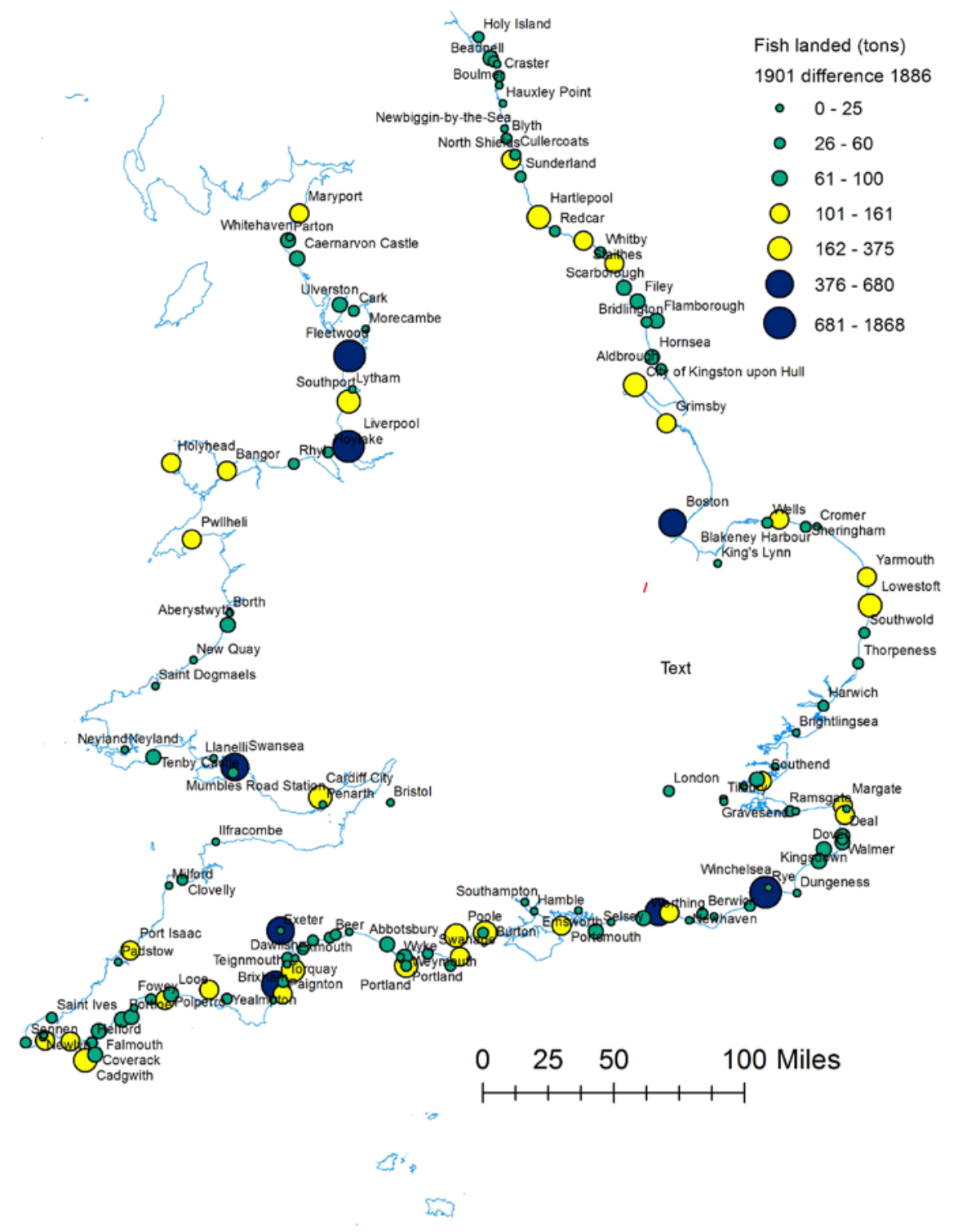

Figure 5 - Tons of fish landed in the fisheries of England and Wales, 1886 and 1901

Sources: British Parliamentary Papers, Return of the Quantity of Fish conveyed Inland by Railway from each of the principal Fishing Ports of England and Wales, Scotland, and Ireland in the Year 1878, 1879-1902.

HoST - Journal of History of Science and Technology 12, pp. 106-131

DOI 10.2478/host-2018-0005 
The pattern shows substantial increases in major ports of the east coast-Sunderland, Hull, Grimsby, Yarmouth, and Lowestoft - and smaller increases in a few of the ports on the English Channel and three or four ports in the southwest and northwest of England and in south Wales. On the west coast Fleetwood saw the greatest percentage increase from 1886 to 1901, reflecting the new practice of Fleetwood trawlers fishing the plentiful cod-fish banks of Iceland. In sum, large ports such as Grimsby and Lowestoft with fleets targeting the prolific North Sea remained predominant while west coast fisheries working the Irish Sea and the cod banks of Iceland joined the upper ranks (Table1).

Table 1 - Increases and decreases in fish landed in England and Wales, 1886 vs. 1901

\begin{tabular}{|l|l|l|l|l|l|}
\hline Coast & Port & M Tons 1886 & M Tons 1901 & Difference & Percent change \\
\hline \multicolumn{5}{|c|}{ Largest Increases } \\
\hline East & Grimsby & 69271 & 136302 & 67031 & +197 \\
\hline East & Hull & 20360 & 74170 & 53810 & +364 \\
\hline East & Lowestoft & 25507 & 78566 & 53059 & +308 \\
\hline East & Yarmouth & 37421 & 67555 & 30135 & +181 \\
\hline West & Milford & 289 & 16830 & 16541 & +5824 \\
\hline West & Fleetwood & 708 & 10354 & 9646 & +1462 \\
\hline South & Penzance (\& Newlyn) & 4203 & 10742 & 6539 & +256 \\
\hline East & Boston & 1896 & 7981 & 6085 & +421 \\
\hline West & Liverpool & 161 & 3585 & 3424 & +2227 \\
\hline West & Swansea & 301 & 3510 & 3209 & +1166 \\
\hline & & \multicolumn{2}{|l|}{ Greatest Decreases } & & \\
\hline East & London & 66225 & 39322 & -26903 & -59 \\
\hline South & Mevagissey & 12948 & 1839 & -11108 & -14 \\
\hline West & St. Ives & 5165 & 2788 & -2377 & -54 \\
\hline West & Neyland & 7997 & 5884 & -2113 & -74 \\
\hline East & Whitby & 2859 & 851 & -2008 & -30 \\
\hline East & Lynn & 1868 & 20 & -1848 & -1 \\
\hline West & Douglas (IOM) & 2098 & 687 & -1411 & -33 \\
\hline South & Hastings & 2389 & 1155 & -1234 & -48 \\
\hline East & Berwick & 2929 & 1731 & -1198 & -59 \\
\hline
\end{tabular}

Sources: The same sources as for Figure 5. Table created by the author. 
That London and its market of Billingsgate saw declines in the tons of fish brought there resulted from interplay of railway expansion and changing market conditions. Thanks to greater rail service accessibility, vessel owners by the 1880 s had greater choices for marketing their catches. More fish than before was sent to inland markets rather than to London. As we saw in testimony of 1863, the travels of William McKrow to open new markets in Scotland and the preference by fishermen in Hull for provincial markets rather than London attest to the trend. Moreover, by the 1880 s telegraphic service made it easier to identify markets where higher prices offered opportunities for greater profits. The search for better prices also aimed at meeting the high costs of railway carriage. In testimony before the Select Commission on the Sea Fisheries of 1893, John Little, a trawler owner at Plymouth, speaking for fishermen in his area, was emphatic: "the railway rates kill us in the West of England; we are under the Great Western Railway Company, who are continually raising their rates, but the price of the fish does not increase." ${ }^{20}$ In short, fishermen knew well both the great benefits and the costs of railways. In the fresh fish trade, for good or ill, rapid rail transport was critical. Turning now to railways and agriculture, we shall see that farmers in the $1880 \mathrm{~s}$ and 90s were to learn the same basic lessons.

\title{
Railways, Agriculture, and Dairy Farming
}

\author{
"Who can forget 1877, 1879, and now 1881? Wheat poured into Great \\ Britain at an alarming rate, so alarming that the British \\ farmer almost gave up hope; and perchance if the \\ uneducated eye of the British agriculturist had seen \\ the full extent of' the country on which this vast \\ plethora of beef and bread was raised, he would have \\ given up the last thread that bound his hopes together."
}

John Clay, Parliamentary Commissioner, 1882

\footnotetext{
${ }^{20}$ BPP, Report from the Select Committee on Sea Fisheries, Minutes of Evidence, London, 1893, testimony of 9 May 1893, p. 58.
}

HoST - Journal of History of Science and Technology 12, pp. 106-131

DOI 10.2478/host-2018-0005 
In 1860s and 1870s the expansion of railways into rural England and Wales connected farmers with distant markets, stimulating production and increasing profits of cereal farmers in particular. That prosperity did not last. Beginning in the late 1870 s a vast flow of American wheat and meat into British (and European) markets intensified domestic competition and depressed prices. Whereas in France and Germany, tariffs were introduced in the 1880s to support farm incomes against foreign competition, in Britain the government held firmly to its policy of free trade. Hence, British wheat and livestock farmers suffered through the long Agrarian Depression (1876-1896). ${ }^{21}$ With little hope of reversing free trade, English and Welsh farmers pressed the government to reduce rail freight charges. As landlords and tenants entered the depression era, wheat fields shrank year by year (Table 2.), and the search for profitable agricultural alternatives led to the conversion of arable land to pasture for livestock. Similarly, the shift to fruit and vegetable production as well as acreage devoted to market gardening increased.

Table 2 - Wheat acreage in the United Kingdom,

France, Germany, and the United States, 1867 to 1895

\begin{tabular}{|l|l|l|l|l|l|l|l|}
\hline Country & \multicolumn{7}{|c|}{ Years } \\
\hline & 1867 & 1872 & 1877 & 1882 & 1887 & 1892 & 1895 \\
\hline UK & $1,458,000$ & $1,539,000$ & $1,336,500$ & $1,296,000$ & 972,000 & 931,500 & 607,500 \\
\hline France & $7,249,500$ & $6,925,500$ & $6,966,000$ & $6,966,000$ & $6,966,000$ & $7,006,500$ & $7,006,500$ \\
\hline US & $4,991,500$ & $8,464,500$ & $10,651,500$ & $15,025,500$ & $15,228,000$ & $15,633,000$ & $13,770,000$ \\
\hline Germany & & & & $1,882,500$ & $1,903,500$ & $1,984,500$ & $1,944,000$ \\
\hline
\end{tabular}

Source: France, Ministère de l'Agriculture. Statistique Agricole de la France. Résultats généraux de l'enquête décennale de 1892. Paris : Imprimerie nationale, 1897 : 94-95.

For farmers in suitable regions, the shift from plow to pasture and dairy farming proved a viable response to the agrarian crisis. In agriculture, railways proved a doubleedged sword. The same railways that distributed cheap American wheat and meat and depressed prices also prepared the way for a boom in a trade insulated from foreign competition: fresh milk. At mid-century the "milk sheds" of London were concentrated

\footnotetext{
${ }^{21}$ For accounts of the Agrarian Depression, see E. J. T. Collins, ed., The Agrarian History of England and Wales. Volume VII 1850-1914, (Cambridge, England: Cambridge University Press, 2000); N. Koning, (1994). The Failure of Agrarian Capitalism: Agrarian Politics in the UK, Germany, the Netherlands and the USA, 1846-1919 (London: Routledge, 1994); and Richard Perren, Agriculture in depression, 1870-1940 (Cambridge, England: Cambridge University Press, 1994).
}

HoST - Journal of History of Science and Technology 12, pp. 106-131

DOI 10.2478/host-2018-0005 
in the peripheries of the capital, close enough so that horse or hand carting could supply city markets. But as railways extended into the countryside, that cozy geography was upended as the capital's milk sheds, in effect, moved to rural Dorset, Wiltshire, Derbyshire, and as far north as Yorkshire. So long as rail transport was available and reasonably priced, the cost of producing and sending fresh milk in the countryside was substantially less than the cost of production in London. ${ }^{22}$ As Figures 6 and 7 indicate, railway expansion improved the accessibility of railway stations and rail transport for farmers in rural communities with lower population densities. By the 1880s, dairy farmers in Dorset and Wiltshire, for example, could send milk by rail to London at lower prices than their urban competitors and still earn a good profit. Rail transit, by shrinking geographic space and distance, eliminated the advantage of proximity to London and other major cities.

To study the shift from plow to pasture and dairy farming let us turn to Wiltshire county as a good example of the broader pattern of agrarian change. Located in the west of England, the county was a region of mixed farming with considerable acreage in wheat before the agrarian depression. As for rail service, the first rural lines and stations opened in the late 1850s and 1860s. And by the 1880s new lines increased accessibility from any given parish to a rail station.

22 P. J. Atkins, "The Growth of London's Railway Milk Trade, c. 1845-1914," Journal of Transport History 4 (1978): 208-26; D. Taylor, "London's Milk Supply, 1850-1900: A Reinterpretation," Agricultural History 45 (1971): 33-38.

HoST - Journal of History of Science and Technology 12, pp. 106-131

DOI 10.2478/host-2018-0005 


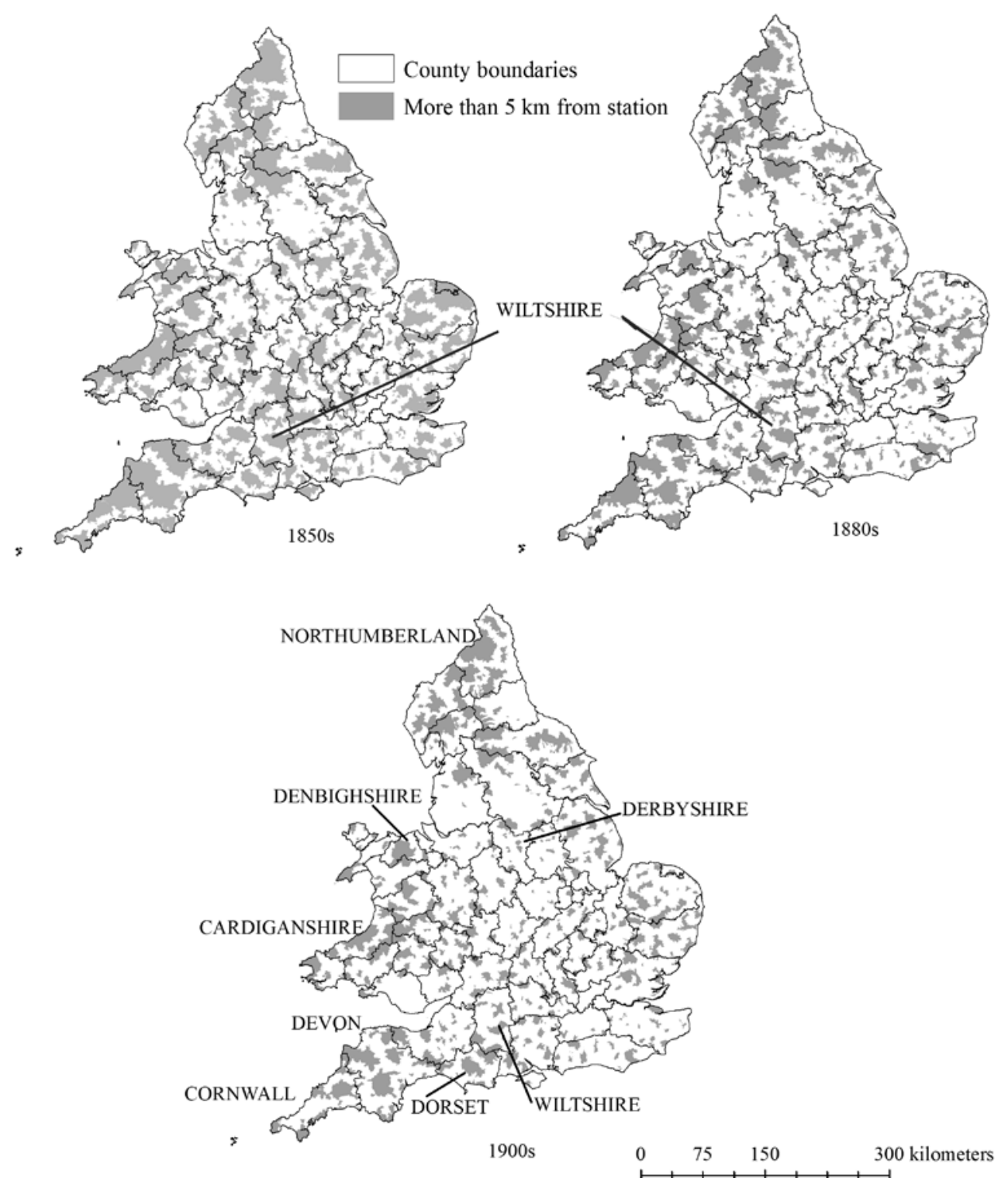

Figure 6 - Improved Accessibility of Rail Transport in England and Wales, 1850-1910

Sources: Figure created by the author from data on rail stations mentioned in note 1; population density figures from parish census data obtained from the Great Britain Historical GIS and Ian Gregory; average distances computed with ArcGIS. Parish boundaries from Ian Gregory; rail lines and stations taken from M.H. Cobb, The Railways of Great Britain, a Historical Atlas, 2 vols. (Shepperton: Ian Allan, 2003) as digitized under the direction of Jordi-Marti Henneberg, University of Lleida, Spain. 
Proximity to a station, of course, was only one aspect of convenient shipping and passenger travel. Poor station facilities, high shipping rates, infrequent trains, delays, inefficient connections from branch to trunk lines—all could add cost and aggravation for rail customers in rural areas. In the case of milk, delays meant spoilage. That said, the accessibility of rural rail service had improved substantially since the late 1860s. This accessibility permitted the shipment of fresh milk from Wiltshire dairy farms to London, Leeds, Manchester, and other cities.

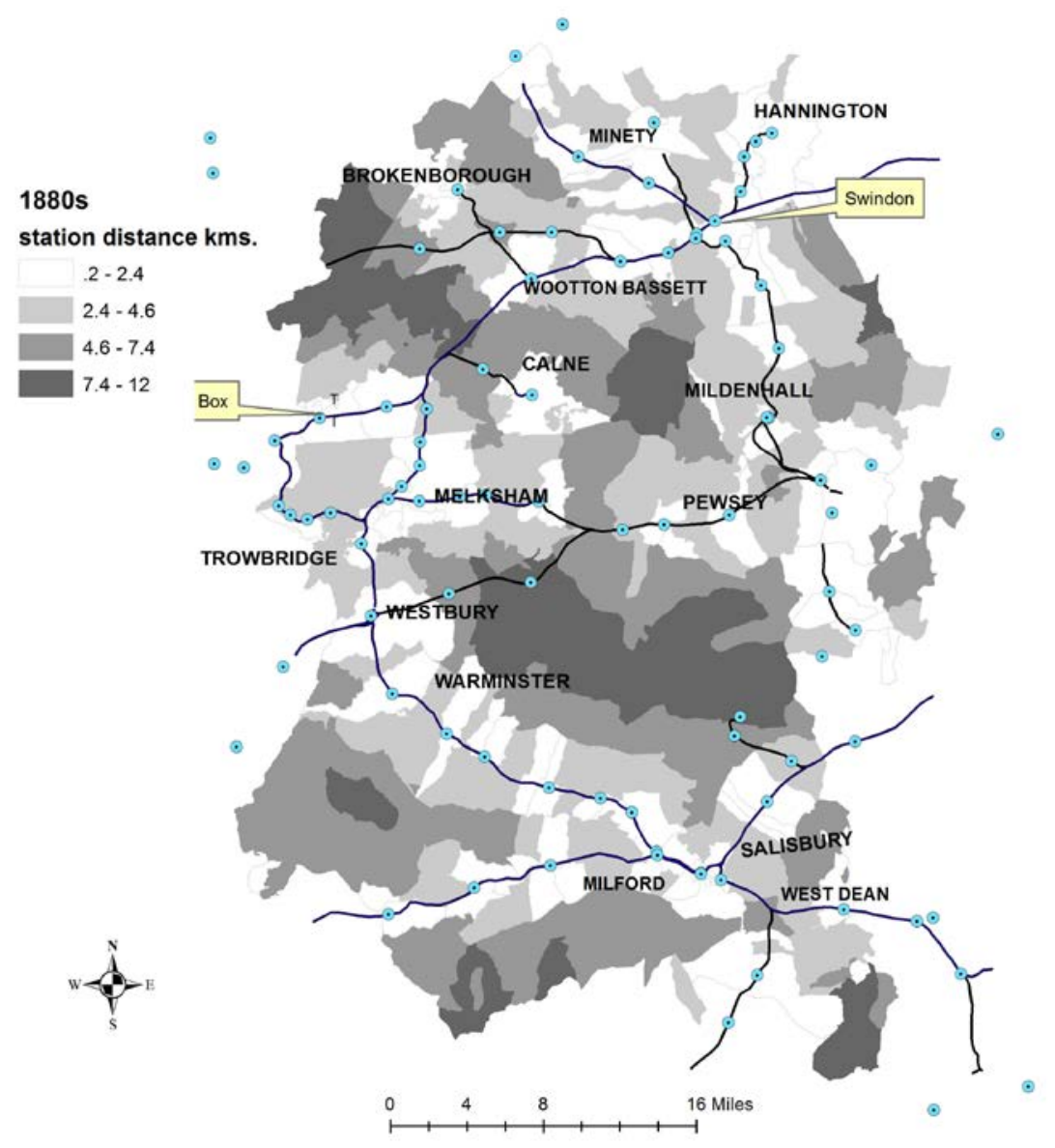

Figure 7- Railway Accessibility in Wiltshire in the 1880s

Sources: railway lines and stations as described in note 1; station distances calculated by the author using ArcGIS. 
After the onset of the agrarian depression in the late 1870s, the contraction of wheat acreage was extensive, as Figure 8 shows. The contraction was especially great in the parishes in the western and northern parts of the county. Where possible, wheat farmers converted much of their land to grass and pasture, taking up livestock raising and dairy farming (see Figure 9).
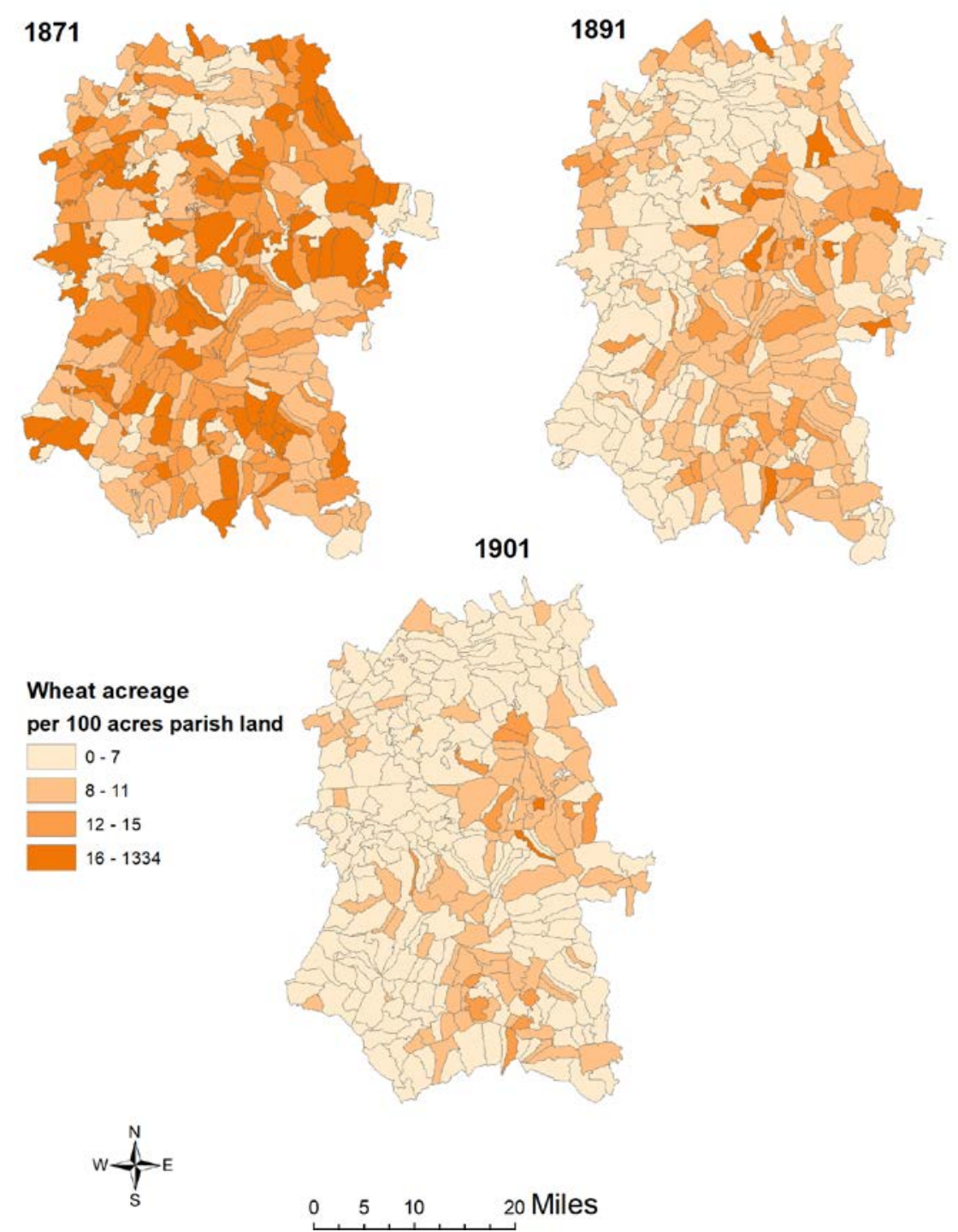

Figure 8 - The Decline of Wheat Production, 1871-1901

Sources: Agricultural Census Returns for Wiltshire County, British National Archives.

HoST - Journal of History of Science and Technology 12, pp. 106-131

DOI 10.2478/host-2018-0005 
By 1891, in the second decade of the agricultural depression, the shift from wheat cultivation to dairy farming was pronounced. Not surprisingly, dairy farming thrived in areas where rail stations were near. Dairy farmers so favored readily sent their milk to major markets in Birmingham, London, and elsewhere. Just as rapid rail transport was indispensable in the fresh fish trade, so it was in the fresh milk trade, too.

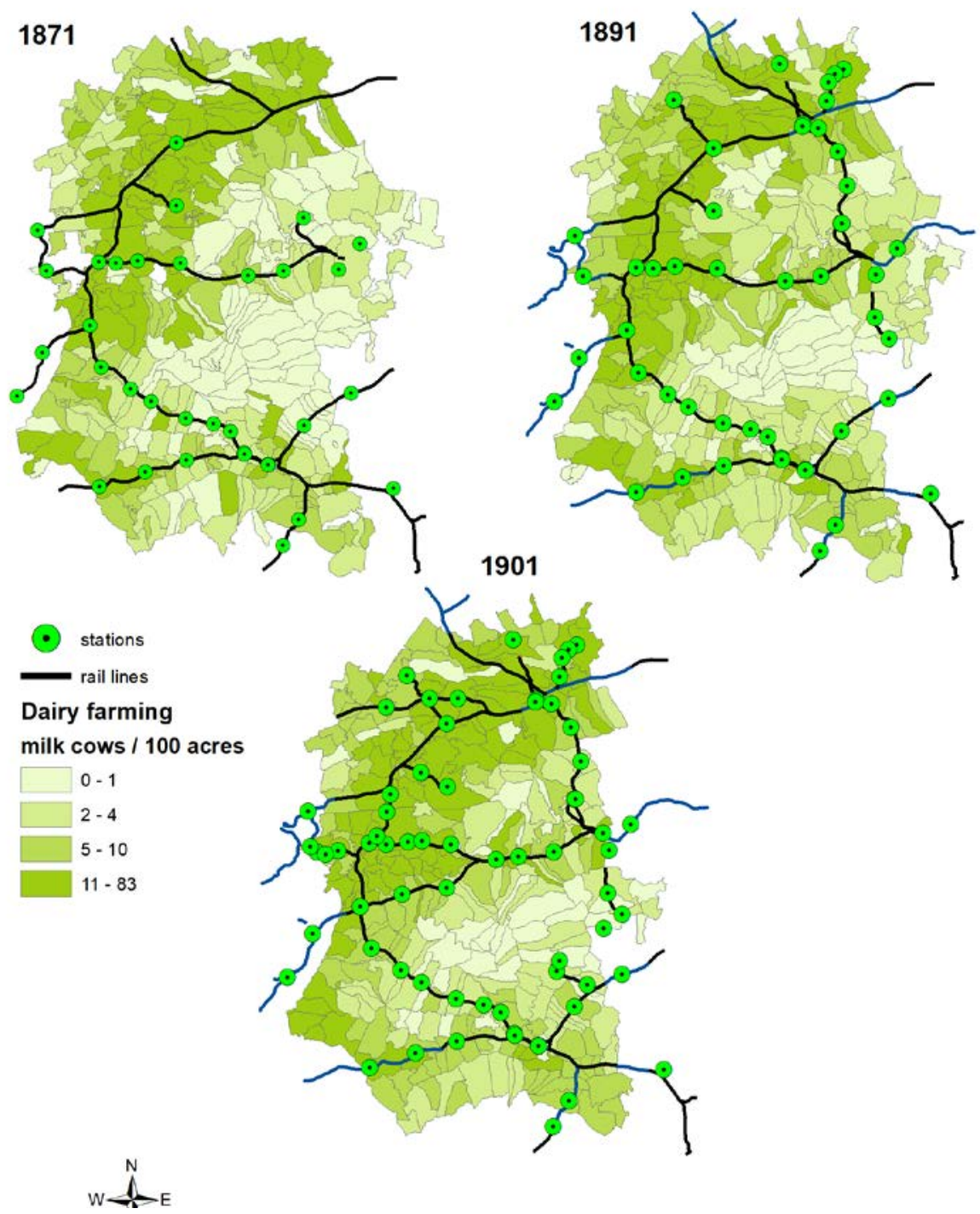

Figure 9 - The Growth of dairy farming and the fresh milk trade, 1871-1901 Sources: Agricultural Census Returns for Wiltshire County, British National Archives.

HoST - Journal of History of Science and Technology 12, pp. 106-131

DOI 10.2478/host-2018-0005 


\section{Conclusion: Railways and Multi-Dimensional Change}

Thus, were some of the effects of the transport revolution on sea fishing and agriculture in Britain during the second half of the nineteenth century. Lest we omit the role of steam ships, ocean freight, and telegraphy at the global level of change, we need to recall John Clay's remarks about the wonders of the American wheat trade. The American acreage in wheat was enormous, the American railway system was vast, and towering grain elevators in Chicago sorted wheat into reliable, graded qualities more efficiently than any of other country. ${ }^{23}$ Thanks to commodity markets and telegraphy, the daily U.S. prices of wheat by type and quality were transmitted to buyers in Britain via newspaper reports in Liverpool and London (Figure 10). From Chicago wheat was sent first by rail to New York city and then by steamship to Liverpool. It arrived there at a price lower than the price British wheat farmers needed to stay in business. ${ }^{24}$ English railways then brought the cheaper wheat to the inland markets.

These were the interconnecting activities and infrastructures at the global scale of resolution. They are the necessary background for stories recounted here at the national, regional, and local scales in Great Britain. With sea fishing and the trade in fresh fish we move into the local scale through the testimony of fishermen at different ports. In non-perishable foodstuffs such as wheat there were interconnections of change at the global and regional scales. Bountiful wheat harvests in Nebraska, U.S.A., seriously affected Norfolk county's wheat growers because depressed prices undermined their livelihoods. Preserved fish from Newfoundland, when imported, could undermine the price of cured fish produced in England. The connecting links were components of transport infrastructure: steam ships and railways. Telegraphic communication made commercial decisions across huge spaces a daily or hourly possibility and practice.

Perishable commodities, on the other hand, were objects of domestic trade, which before the advent of combustion-engine alternative, were fully dependent upon rail transport. As fishermen suggested, railways opened opportunities to reach more

${ }^{23}$ William Cronon, Nature's Metropolis Chicago and the Great West (New York: W. W. Norton, 1991), chap. 3 .

${ }^{24}$ Perren, Agriculture in depression, 8. 
profitable markets than London, just as high carriage rates could block or diminish opportunities. More broadly, railways together with steam-powered trawlers came to undermine the ecological foundations of sea fishing and fish reproduction. In the Special Committee on Fisheries of 1893 some witnesses spoke with concern about overfishing and diminishing returns in the form of smaller and inferior qualities of landed fish. ${ }^{25}$ In sum, railways were multi-dimensional agents of change in human and physical environments.

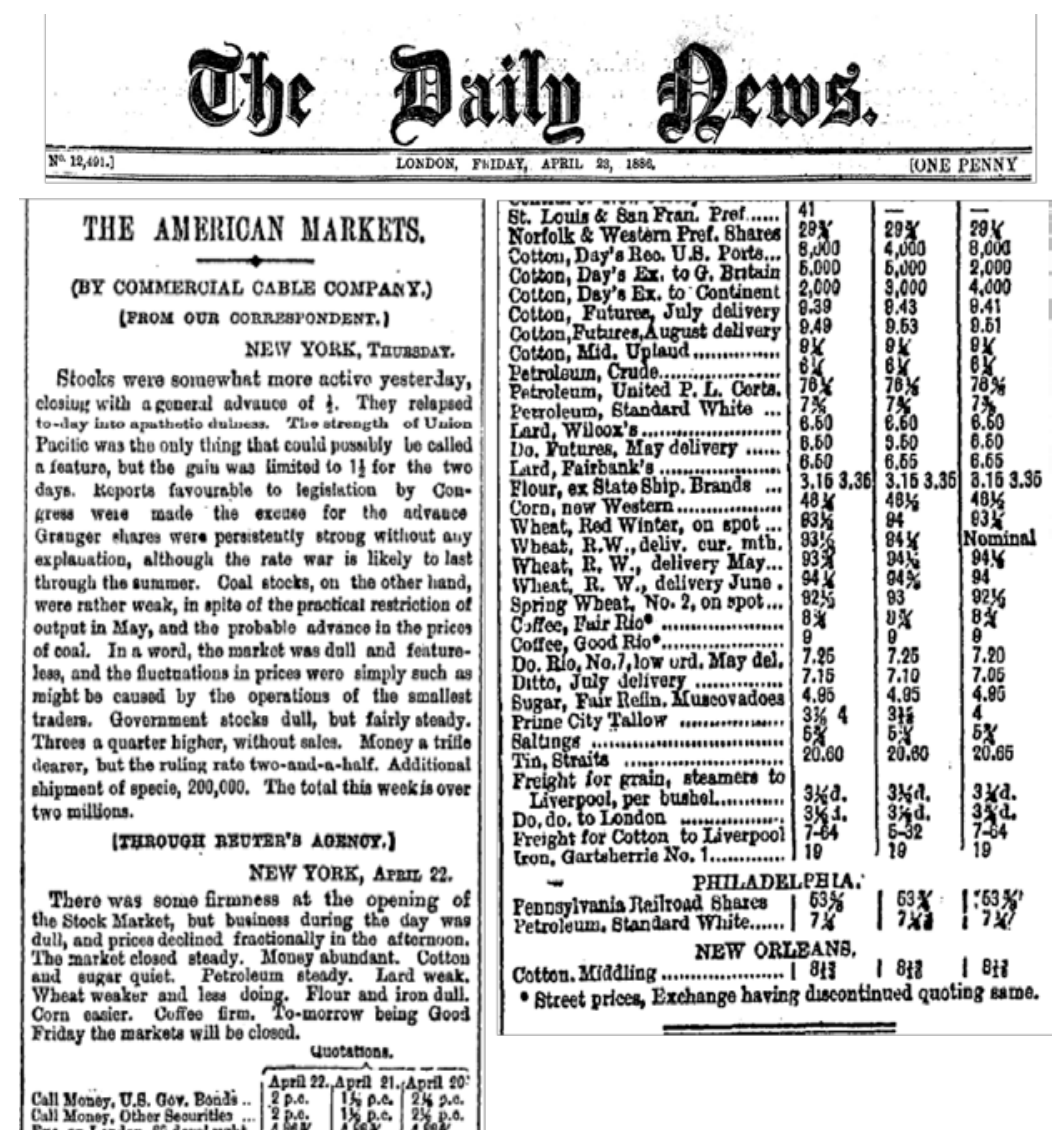

Figure 10 - American Wheat Prices in the London Daily News, April 23, 1886, p. 6, quotations of April 22 by telegraph.

\footnotetext{
${ }^{25}$ The Select Commission on Sea Fisheries of 1893 [BPP] heard testimony from 60 witnesses, the majority of whom expressed concerns about the decline in the quality and number of fish being taken and of certain fishing banks being overfished. The Commission's report gave official recognition to the term "overfishing" and to the depletion of sole, flounder, and other flat fish.
}

HoST - Journal of History of Science and Technology 12, pp. 106-131

DOI 10.2478/host-2018-0005 
This article demonstrates how the collaborating components of spatial history can and do lead to new findings and discoveries. Digging into historical information and presenting geo-historical patterns in visual forms-maps, tables, graphs-prompts both additional questions and insights into spatio-temporal relationships that other approaches, however useful, ignore. The various social meanings underlying maps of spatial connections, for example, remain obscure or hidden without evidence on human experiences within the spatio-temporal frame. In this article the best example is the testimony of fishermen and fishing industry representative before Parliamentary commissions. Many a historian has consulted such Parliamentary evidence by turning quickly to the summaries, avoiding the hundreds of pages of individual testimonies. The result of this practice is some summary of the commission's conclusions, which reflect the outlook of commissioners as opposed to those of the witnesses. Using CAQDAS makes it possible to recover the outlook of witnesses in hundreds of pages of testimony. Paired with GIS spatial analysis, the results, for example, a growing awareness by fisherman themselves that fish from the sea was not an inexhaustible resource. 